BIODIK: Jurnal IImiah Pendidikan Biologi
ISSN 2580-0922 (online), ISSN 2460-2612 (print)
Volume 6, Nomor 02, Tahun 2020, Hal. 106-117
Available online at:
https://online-journal.unja.ac.id/biodik

Research Article OPEN ACCESS

\title{
Kelayakan Lembar Kerja Peserta Didik Berbasis Model Pembelajaran Search, Solve, Create and Share pada Praktikum Materi Fungi
}

\section{(The Feasibility of Students' Worksheet Based on Search, Solve, Create and Share Instructional Model in Fungi Practicum Material)}

Annur Wulan Putriyana, Lia Auliandari, Kholillah

Pendidikan Biologi, Universitas Muhammadiyah Palembang

JIn. Jendral A. Yani 13 Ulu Palembang-Indonesia 30263 TIp. 510842.

${ }^{*}$ Corresponding Author: wulanputriyanaannur@gmail.com

\begin{tabular}{|c|c|}
\hline Informasi Artikel & ABSTRACT \\
\hline $\begin{array}{l}\text { Submit: } 08-05-2020 \\
\text { Diterima: } 17-05-2020 \\
\text { Dipublikasikan:03-06-2020 }\end{array}$ & $\begin{array}{l}\text { This research was motivated by Student Worksheets on Fungi Practicum Material } \\
\text { which were categorised as incapable to provide opportunities for students to } \\
\text { autonomously discover learning concepts. Material on Fungi requires active } \\
\text { learning activities, such as observation, experiment and literature review. This study } \\
\text { aims to seek the feasibility of Students' Worksheets based on the SSCS (Search, } \\
\text { Solve, Create and Share) Instructional Model according to expert review on Fungi } \\
\text { Practicum in SMA Patra Mandiri } 1 \text { Palembang. This study applies quantitative } \\
\text { descriptive method to assess the feasibility according to expert review (which } \\
\text { includes three content validators, three material validators and two teachers) using } \\
\text { questionnaires. The data analysis uses five scales (strongly impractical, impractical, } \\
\text { sufficiently feasible, feasible and strongly feasible). The results show the total score } \\
\text { of } 94.67 \text { (feasible) for validity on the learning content, } 77 \text { (feasible) on the learning } \\
\text { material and } 91 \text { (strongly feasible) on the teachers. Revisions are made regarding } \\
\text { to image clarity. } \\
\text { Keywords: Quantitative Descriptive, Student Worksheet Based on SSCS } \\
\text { Instructional Model, Fungi. }\end{array}$ \\
\hline Penerbit & ABSTRAK \\
\hline $\begin{array}{l}\text { Program Studi Pendidikan } \\
\text { Biologi, Fakultas Keguruan dan } \\
\text { Ilmu Pendidikan, Universitas } \\
\text { Jambi }\end{array}$ & $\begin{array}{l}\text { Penelitian ini dilatarbelakangi oleh belum sesuainya Lembar Kerja Peserta Didik } \\
\text { (LKPD) untuk praktikum pada materi Fungi sehingga belum mampu memberi } \\
\text { kesempatan bagi peserta didik untuk dapat menemukan sendiri konsep-konsep } \\
\text { yang peserta didik pelajari. Materi fungi merupakan materi yang membutuhkan } \\
\text { peran aktif peserta didik dengan adanya pengamatan dan percobaan serta kajian } \\
\text { literatur. Penelitian ini bertujuan untuk mengetahui kelayakan Lembar Kerja } \\
\text { Peserta Didik (LKPD) berbasis model pembelajaran SSCS (Search, Solve, Create } \\
\text { and Share) berdasarkan penilaiam Expert review pada praktikum materi Fungi } \\
\text { kelas X SMA Patra Mandiri } 1 \text { Palembang. Penelitian ini menggunakan metode } \\
\text { deskriptif kuantitatif untuk penilaian kelayakan berdasarkan Expert review (meliputi } \\
\text { tiga validator bahan ajar, tiga validator materi, dan dua guru) dengan menggunakan } \\
\text { angket. Analisis data mengacu pada modifikasi Azwar rentang skor } 1-5 \text { dengan } \\
\text { interpretasi kelayakan (sangat tidak layak, kurang layak, cukup layak, layak dan } \\
\text { sangat layak). Hasil penelitian menunjukkan bahwa penilaian kelayakan LKPD } \\
\text { berdasarkan penilaian dari validator bahan ajar adalah } 94,67 \text { (layak), penilaian dari } \\
\text { validator materi adalah } 77 \text { (layak) dan penilaian dari guru adalah } 91 \text { (sangat layak). } \\
\text { Walaupun telah dinyatakan layak dan sangat layak namun terdapat revisi } \\
\text { mengenai gambar yang perlu diperjelas lagi. } \\
\text { Kata kunci: Deskriptif Kuantitatif, LKPD Berbasis Model Pembelajaran SSCS, } \\
\text { Fungi }\end{array}$ \\
\hline
\end{tabular}


This BIODIK : Jurnal IImiah Pendidikan Biologi is licensed under a CC BY-NC-SA (Creative Commons Attribution-ShareAlike 4.0 International License)

\section{PENDAHULUAN}

Biologi merupakan salah satu ilmu pengetahuan alam yang mempelajari makhluk hidup dan kehidupannya dari berbagai aspek persoalan dan tingkat organisasinya. IImu pengetahuan alam juga tidak hanya berkaitan dengan cara mencari tahu tentang alam secara sistematis, tetapi juga merupakan suatu proses penemuan untuk menumbuhkan kemampuan berpikir ilmiah, bekerja dan bersikap ilmiah serta mengkomunikasikannya sebagai aspek penting. Hal ini pun sejalan dengan pendapat Rahmatika (2014) dan Carolina, Sutanto, dan Suseno (2017) yang menyatakan bahwa biologi merupakan bagian dari IImu Pengetahuan Alam yang bukan mencari tahu tentang kumpulan pengetahuan yang berupa fakta-fakta atau konsep-konsep. Namun, biologi juga dapat menumbuhkan kemampuan berpikir ilmiah dan keterampilan proses sains. Keterampilan proses sains meliputi keterampilan mengamati dengan seluruh indera, menggunakan alat dan bahan, menganalisis data, membuat kesimpulan percobaan dan mengkomunikasikan hasil percobaan.

Pemanfaatan laboratorium merupakan suatu proses dalam memanfaatkan sarana laboratorium dengan menggunakan teknik atau cara tertentu dalam menunjang pemahaman peserta didik terhadap materi pelajaran. Hal ini dipertegas dengan pendapat Sobiroh (2006) dan Hidayati (2013) yang menyatakan bahwa laboratorium atau kegiatan praktikum merupakan bagian dari proses belajar mengajar yang dapat mengkomunikasikan hasil percobaan. Pentingnya penggunaan laboratorium menurut pendapat Puspa, Lubis, dan Rizkika (2017) peserta didik mendapat kesempatan untuk menguji dan melaksanakan kegiatan dalam keadaan nyata. Kegiatan praktikum biologi dapat membangkitkan motivasi belajar, praktikum mengembangkan kemampuan dasar melakukan eksperimen, praktikum menjadi wahana pendekatan ilmiah dan praktikum menunjang materi pelajaran. Pentingnya penggunaan laboratorium di sekolah untuk menunjang pemahaman peserta didik. Namun masih banyak yang belum memanfaatkan laboratorium di sekolah, seperti pendapat Elseria (2016) banyak laboratorium IPA yang ada di sekolah belum dimanfaatkan secara optimal, hal ini disebabkan kurangnya minat, pengetahuan pengelolaan dan penggunaan dalam pemanfaatan sumber daya manusia yang ada di laboratorium tersebut.

Pemilihan dan penentuan LKPD untuk praktikum adalah memenuhi salah satu kriteria bahwa lembar kerja peserta didik harus menarik, dapat membantu siswa untuk mencapai kompetensi dan harus memuat petunjuk praktikum. Menurut Diniaty dan Atun (2015), sistematika lembar kerja peserta didik untuk praktikum adalah 1) judul, 2) pengantar, 3) tujuan, 4) alat dan bahan, 5) langkah kerja, 6) tabel pengamatan, 7) pertanyaan. LKPD digunakan untuk membimbing peserta didik supaya melakukan keterampilan proses sains (Dewi, R., Budiarti, R. S., \& Aina, M, 2017). 
Berdasarkan hasil wawancara pada tanggal 11 Desember 2018 dengan Guru Mata Pelajaran Biologi di SMA Patra Mandiri 1 Palembang diperoleh informasi bahwa di sekolah tersebut telah menggunakan Kurikulum 2013 sejak tahun 2013. Pada proses pembelajaran guru sudah menggunakan metode praktikum. Hal ini juga dipertegas dengan hasil wawancara peserta didik kelas XI bahwa pada saat mereka kelas $\mathrm{X}$ memang benar guru melaksanakan kegiatan praktikum.

Lembar Kerja Peserta Didik (LKPD) praktikum dibuat sendiri oleh guru untuk melaksanakan kegiatan praktikum. Namun, hasil observasi masih ada LKPD yang belum menggunakan metode praktikum yaitu materi Fungi, sehingga belum mampu memberi kesempatan bagi peserta didik untuk dapat menemukan sendiri konsepkonsep yang peserta didik pelajari. Untuk megatasi hal tersebut, maka diperlukan sebuah inovasi dalam LKPD materi Fungi dengan menggunakan Model SSCS (Search, Solve, Create and Share). Menurut Sa'diyati (2011), materi fungi merupakan materi yang membutuhkan peran aktif peserta didik. Hal ini terkait dengan Kompetensi Dasar 4.7 yang harus dikuasai peserta didik, yaitu dengan adanya pengamatan dan percobaan serta kajian literatur. LKPD yang dibuat oleh guru belum mampu membuat peserta didik memiliki peran aktif dalam kegiatan praktikum.

Model pembelajaran SSCS juga memiliki kelebihan dan kekurangan dalam kegiatan pembelajaran. Kelebihan model pembelajaran SSCS yaitu: 1) dalam model pembelajaran SSCS, siswa dihadapkan pada masalah-masalah nyata yang diberikan oleh guru pada awal pembelajaran, sehingga siswa merasa tertarik untuk belajar, 2) dalam model pembelajaran SSCS, siswa lebih sering belajar secara kelompok dan guru lebih banyak memberikan kesempatan pada siswa untuk menyelesaikan masalah mereka sendiri, dan 3) Kegiatan siswa dalam model pembelajaran SSCS sangat bervariasi mulai dari diskusi, melakukan percobaan, dan presentasi yang membuat siswa semangat dan tidak jenuh mengikuti pelajaran. Sedangkan kekurangan model pembelajaran SSCS menurut peserta didik masih belum terbiasa menggunakan model pembelajaran SSCS, sehingga siswa hanya mendengarkan dan mencatat keterangan yang diberikan oleh guru atau dari temannya (Saputra, Sumarjono, dan Purwaningsih, 2014).

Berdasarkan pendapat BalRam (2017), kegiatan praktikum memberikan kesempatan siswa untuk memperoleh pengetahuan episode dan semua kejadian nyata yang ada. Pengetahuan episode merupakan pengetahuan yang memiliki retensi yang tinggi sehingga dapat lama diingat dan lebih mudah untuk digunakan kembali.

Penerapan Model Pembelajaran SSCS (Search, Solve, Create and Share) dalam LKPD untuk praktikum sangat bermanfaat karena model pembelajaran SSCS ini memakai pendekatan problem solving yang didesain untuk mengembangkan keterampilan berpikir kritis siswa dan meningkatkan pemahaman siswa terhadap konsep ilmu. Penguasaan konsep lebih dari sekedar memahami konsep dan keterampilan berpikir kritis siswa akan dapat tercapi jika siswa telah menguasai konsep. Hal ini sejalan dengan pendapat Saputra, Sumarjono, dan Purwaningsih (2014) bahwa siswa yang belajar menggunakan model SSCS menunjukkan adanya 
pengaruh signifikan terhadap prestasi belajar. Prestasi belajar terdiri dari aspek kognitif, psikomotor, dan afektif.

Model Pembelajaran SSCS (Search, Solve, Create and Share) cocok digunakan dalam pelaksanaan praktikum dengan materi fungi. Materi Fungi ini dapat dikaitkan dari materi yang dipelajarinya dengan lingkungan sekitar. LKPD berbasis Model Pembelajaran SSCS (Search, Solve, Create and Share) dapat memudahkan peserta didik dalam memahami jamur tersebut karena jamur dapat dengan mudah dijumpai di lingkungan sekitar sehingga memudahkan peserta didik melihat objek secara langsung.

Lembar Kerja Peserta Didik (LKPD) yang dibuat dengan Berbasis Model Pembelajaran SSCS (Search, Solve, Create and Share) pada Praktikum Materi Fungi Kelas $\mathrm{X}$ diperlukan uji kelayakan oleh Expert review (meliputi validator bahan ajar 3 orang, validator materi 3 orang dan pengguna (guru) 2 orang), untuk memenuhi kaidahnya baik dari segi sistematika penulisan, isi, dan penyajian LKPD tersebut agar peserta diidk dapat menemukan sendiri konsep-konsep yang peserta didik pelajari. Hal ini pun dipertegas oleh Haqsari (2014) yang menyatakan bahwa pembuatan LKPD seharusnya sesuai dengan standar isi, sistematis, sederhana, praktis dan mudah dimengerti, sehingga dapat digunakan secara optimal oleh peserta didik. Hal ini sesuai dengan yang telah dijelaskan pada latar belakang. Tujuan penelitian ini adalah mengetahui kelayakan Lembar Kerja Peserta Didik (LKPD) berbasis Model Pembelajaran SSCS (Search, Solve, Create and Share) Berdasarkan Penilaian Expert review pada pada Praktikum Materi Fungi Kelas $\mathrm{X}$ SMA Patra Mandiri 1 Palembang.

\section{METODE PENELITIAN}

Penelitian yang dilakukan merupakan penelitian deskriptif kuantitatif yang bertujuan untuk mengetahui kelayakan produk Lembar Kerja Peserta Didik (LKPD) berbasis Model Pembelajaran SSCS (Search, Solve, Create and Share) pada praktikum materi Fungi kelas X SMA Patra Mandiri 1 Palembang. Penelitian ini tingkat keberhasilannya berdasarkan data kuantitatif kelayakan LKPD. Penelitian ini tidak memberikan perlakuan apapun kepada subjek, tetapi pengambilan data dilakukan melalui lembar angket, sedangkan data dari daftar wawancara dan lembar analisis kebutuhan awal siswa sebagai data pendahuluan untuk kebutuhan dilakukannya penelitian. Subjek penelitian ini adalah validator untuk LKPD berbasis Model Pembelajaran SSCS (Search, Solve, Create and Share). Validator tesebut terdiri atas validator bahan ajar 3 orang, validator materi 3 orang dan pengguna (guru) 2 orang. Validator bahan ajar, materi dan pengguna (guru) adalah Expert review dalam penelitian kelayakan LKPD. Intrumen penelitian ini adalah daftar wawancara, lembar analisis kebutuhan siswa dan lembar angket. Daftar wawancara dan lembar analisis kebutuhan awal siswa digunakan sebagai data pendahuluan untuk kebutuhan dilakukannya penelitian sedangkan lembar angket ini digunakan untuk mengetahui kelayakan LKPD oleh validator bahan ajar, validator materi dan pengguna (guru). Data penelitian ini dianalisis secara kuantitatif. Kelayakan LKPD yang telah dibuat mengacu pada Modifikasi Azwar (2014), dengan menggunakan 
perhitungan skala Likert (dengan rentang 1-5). Acuan tersebut ditampilkan dalam Tabel 1.

Tabel 1. Kelayakan LKPD Berbasis Model Pembelajaran SSCS

\begin{tabular}{cc}
\hline Rentang Skor & Interpretasi Kelayakan \\
$\mathrm{Mi}+1,5 \mathrm{SBi}<\mathrm{X}$ & Sangat Layak \\
$\mathrm{Mi}+0,5 \mathrm{SBi}<\mathrm{X} \leq \mathrm{Mi}+1,5 \mathrm{SBi}$ & Layak \\
$\mathrm{Mi}-0,5 \mathrm{SBi}<\mathrm{X} \leq \mathrm{Mi}+0,5 \mathrm{SBi}$ & Cukup Layak \\
$\mathrm{Mi}-1,5 \mathrm{SBi}<\mathrm{X} \leq \mathrm{Mi}-0,5 \mathrm{SBi}$ & Kurang Layak \\
$\mathrm{X}<\mathrm{Mi}-1,5 \mathrm{SBi}$ & Sangat Tidak Layak \\
\hline
\end{tabular}

(Sumber: Modifikasi Azwar, 2014).

\section{HASIL PENELITIAN DAN PEMBAHASAN}

Hasil penelitian ini menjawab penelitian yang bertujuan untuk menguji kelayakan LKPD berbasis Model Pembelajaran SSCS (Search, Solve, Create and Share) pada praktikum materi Fungi. LKPD ini pun perlu dilakukan uji kelayakannya mengenai tata tulis, tata bahasa atau kalimat yang dianggap belum tepat nantinya akan diperbaiki di dalam LKPD. LKPD ini akan diuji kelayakannya oleh validator bahan ajar, validator materi dan pengguna (guru). Berikut ini hasil penelitian dan deskripsi prosedur kelayakan LKPD sehingga diperoleh LKPD yang layak.

1. Hasil Validator Bahan Ajar

Berdasarkan hasil validasi dari tiga validator bahan ajar, ada beberapa yang perlu diperbaiki dalam pembuatan LKPD yang diuji kelayakannya. Hasil penilaian dari ketiga validator bahan ajar kemudian dirata-ratakan dapat dilihat pada Tabel 2 diperoleh nilai 94,67 yang artinya bahan ajar LKPD termasuk kategori layak berdasarkan penilaian validator bahan ajar.

Tabel 2 Hasil Validasi Oleh Validator Bahar Ajar

\begin{tabular}{ccccc}
\hline \multirow{2}{*}{ Indikator } & \multicolumn{3}{c}{ Penilaian Validator Bahan Ajar } & \multirow{2}{*}{ Rata-rata } \\
\cline { 2 - 4 } & Validator 1 & Validator 2 & Validator 3 & \\
\hline Jumlah & 89 & 96 & 99 & 94,67 \\
Kategori & Layak & Layak & Layak & Layak \\
\hline
\end{tabular}

Penilaian validator bahan ajar ini dilakukan oleh tiga orang validator untuk mengetahui kelayakan LKPD berbasis model pembelajaran SSCS (Search, Solve, Create and Share) pada praktikum materi Fungi didasarkan pada delapan indikator, yaitu meliputi ukuran LKPD, desain sampul LKPD, desain isi LKPD, penyajian pembelajaran, lugas, dialogis dan interaktif, kesesuaian dengan kaidah bahasa indonesia dan penggunaan istilah, simbol atau ikon.

Berdasarkan hasil analisis penilaian validator yang tercantum dalam Tabel 2, validator pertama menyatakan bahwa LKPD tersebut layak, validator kedua menyatakan bahwa LKPD tersebut layak dan validator ketiga menyatakan bahwa LKPD tersebut layak. Hasil rata-rata dari ketiga validator tersebut yaitu 94,67 yang artinya LKPD tersebut layak dalam segi bahan ajarnya.

Berdasarkan pehitungan dengan rumus Azwar (2014) bahan ajar LKPD telah dinyatakan layak karena telah memenuhi indikator Badan Standar Nasional Pendidikan (BSNP) dengan interval 83,3 $<X \leq 99,9$. Walaupun LKPD dinyatakan 
layak, namun ada beberapa revisi dari validator bahan ajar yaitu, judul pada halaman sampul tidak terlihat jelas jadi untuk menyiasati hal tersebut warna dari latar belakang diubah menjadi warna hijau dan judul diubah menjadi warna hitam agar dapat menarik peserta didik untuk membaca. Hal ini pun sejalan dengan pendapat Basri, dkk. (2019) yang menyatakan bahwa Lembar Kerja Peserta Didik (LKPD) yang dirancang harus semenarik mungkin mulai dari penggunaan warna, kejelasan dan daya tarik gambar guna mempermudah peserta didik untuk memahami isi dari LKPD. Hasil revisi dari validator bahan ajar dapat dilihat pada Gambar 1.
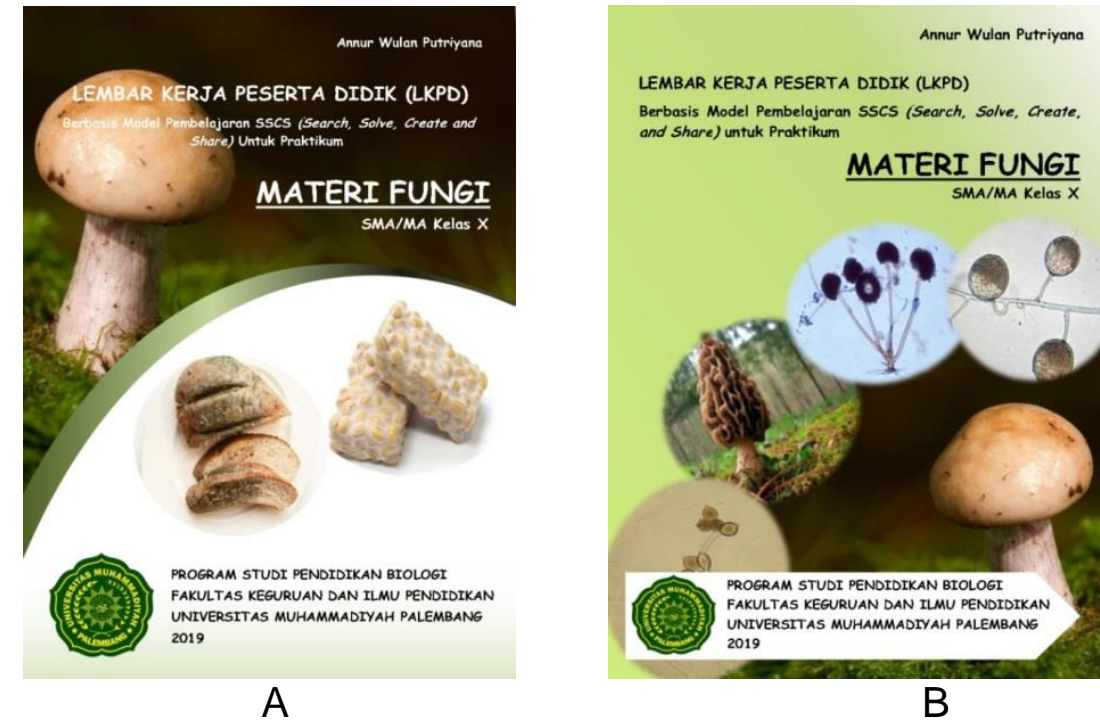

Gambar 1. (A) Halaman sampul sebelum direvisi oleh Validator Bahan Ajar (B) Halaman sampul sesudah direvisi oleh Validator Bahan Ajar.

Hasil komentar dari validator bahan ajar tidak hanya terkait dengan judul dan warna latar belakang, namun gambar yang terdapat di halaman sampul dan gambar yang terdapat di biografi penulis perlu diubah, untuk gambar pada halaman sampul perlu diubah karena tidak sesuai dengan materi yang disampaikan. Materi yang sampaikan yaitu materi Fungi, jadi sebaiknya gambar pada halaman sampul adalah gambar yang mewakili dari masing-masing filum Fungi agar dapat menarik peserta didik untuk membuka LKPD tersebut dan untuk gambar yang terdapat dibiografi penulis sebaiknya diperbesar saja agar gambar terlihat jelas. Hal ini pun sejalan dengan penelitian Putri dan Mitarlis (2015) yang menyatakan bahwa LKPD yang menarik dapat membantu memotivasi peserta didik karena penyajiannya menggunakan tulisan, warna dan gambar yang sesuai dengan materi. Sehingga, dapat membantu peserta didik dalam memahami materi dan tertarik untuk membuka LKPD tersebut

Hasil komentar dari validator bahan ajar juga tidak hanya mengenai halaman sampul dan biografi penulis saja namun penulisan pada petunjuk Tahap Solve dan Tahap Create juga perlu diperbaiki agar peserta didik dapat mengerti maksud dari langkah kerja tersebut, apabila peserta didik tidak mengerti maka hasil yang akan didapat juga tidak maksimal. Hal ini pun dipertegas dengan pendapat Prastowo (2015) bahwa sesempurna apapun materi, apabila peserta didik tidak mampu membaca petunjuk pada setiap kegiatan, maka LKPD tidak akan memberikan hasil yang maksimal. 


\section{Hasil dan Pembahasan Validator Materi}

Berdasarkan hasil validasi dari tiga validator materi, ada beberapa yang perlu diperbaiki dalam pembuatan LKPD yang diuji kelayakannya. Hasil penilaian dari ketiga validator materi kemudian dirata-ratakan dapat dilihat pada Tabel 3 diperoleh nilai 77 yang artinya bahan ajar LKPD termasuk kategori layak berdasarkan penilaian validator materi.

Tabel 3 Hasil Validasi Oleh Validator Materi

\begin{tabular}{ccccc}
\hline \multirow{2}{*}{ Indikator } & \multicolumn{3}{c}{ Penilaian Validator Materi } & \multirow{2}{*}{ Rata-rata } \\
\cline { 2 - 4 } & Validator 1 & Validator 2 & Validator 3 & \\
\hline Jumlah & 83 & 71 & 77 & 77 \\
Kategori & Sangat Layak & Layak & Layak & Layak \\
\hline
\end{tabular}

Penilaian validator materi ini dilakukan oleh tiga orang validator untuk mengetahui kelayakan LKPD berbasis model pembelajaran SSCS (Search, Solve, Create and Share) pada praktikum materi Fungi didasarkan pada sembilan indikator, yaitu meliputi kesesuaian materi dengan kompetensi dasar, keakuratan materi, kemutakhiran materi, mendorong keingintahuan, teknik penyajian, lugas, dialogis dan interaktif, kesesuaian dengan kaidah bahasa indonesia dan penggunaan istilah, simbol atau ikon.

Berdasarkan hasil analisis penilaian validator yang tercantum dalam Tabel,3, validator pertama menyatakan bahwa LKPD tersebut sangat layak, validator kedua menyatakan bahwa LKPD tersebut layak dan validator ketiga menyatakan bahwa LKPD tersebut layak. Hasil rata-rata dari ketiga validator tersebut yaitu 77 yang artinya LKPD tersebut layak dalam segi materinya.

Berdasarkan pehitungan dengan rumus Azwar (2014) bahan ajar LKPD telah dinyatakan layak karena telah memenuhi indikator Badan Standar Nasional Pendidikan (BSNP) dengan interval $66,6<\mathrm{X} \leq 79,9$. Walaupun LKPD dinyatakan layak, namun ada beberapa revisi dari validator materi yaitu, gambar pada siklus hidup dari masing-masing filum yang kurang jelas dan ada beberapa keterangan gambar yang masih menggunakan Bahasa Inggris diubah semua menjadi Bahasa Indonesia untuk mensiasati hal tersebut gambar semua siklus hidup diganti menjadi gambar yang lebih terlihat jelas lagi dan keterangan gambar pada setiap masingmasing siklus hidup diubah menjadi Bahasa indonesia agar peserta didik dapat memahami siklus hidup dari masing-masing filum dan dapat membaca keterangan gambar siklus hidup dari masing-masing filum dengan jelas. Hal ini pun sejalan dengan penelitian Mujiarti (2014) yang menyatakan bahwa gambar yang digunakan sebaiknya mampu membantu menjelaskan kata-kata yang disampaikan. Oleh karena itu, gambar tersebut harus memiliki kualitas yang baik, dalam arti memiliki tujuan, relevan, jelas, mengandung kebenaran, autentik, aktual, lengkap, sederhana, menarik, dan memberikan sugesti tentang kebenaran itu sendiri. Hasil revisi dari validator materi dapat dilihat pada Gambar 2. 


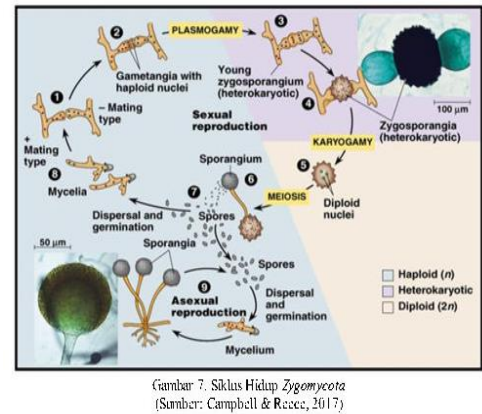

A

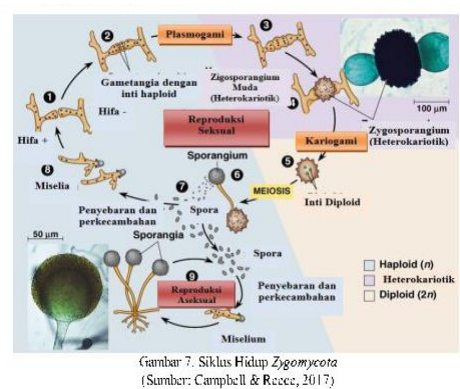

B

Gambar 2. (A) Siklus hidup Zygomycota sebelum direvisi oleh Validator Materi (B) Siklus hidup Zygomycota sesudah direvisi oleh Validator Materi

Hasil komentar dari validator materi juga tidak hanya mengenai gambar saja namun, ada beberapa tambahan yang harus dilengkapi di dalam LKPD meliputi kata pengantar, daftar isi, daftar gambar, daftar tabel, petunjuk penggunaan LKPD, karakteristik LKPD, langkah-langkah model pembelajaran dan glosarium. Penambahan daftar isi, daftar gambar, daftar tabel dan petunjuk penggunaan LKPD perlu dilakukan agar dapat mempermudah peserta didik dalam menggunakan LKPD, untuk karakteristik LKPD dan langkah-langkah model pembelajaran juga perlu di dalam LKPD agar peserta didik dapat memahami karakteristik LKPD tersebut dan peserta didik juga dapat memahami langkah-langkah model pembelajaran yang terdapat di dalam LKPD. Penambahan glosarium juga dapat mempermudah peserta didik dalam mencari istilah-istilah yang kurang dimengerti didalam LKPD. Hasil revisi dari validator materi dapat dilihat pada Gambar 3 sampai Gambar 5.
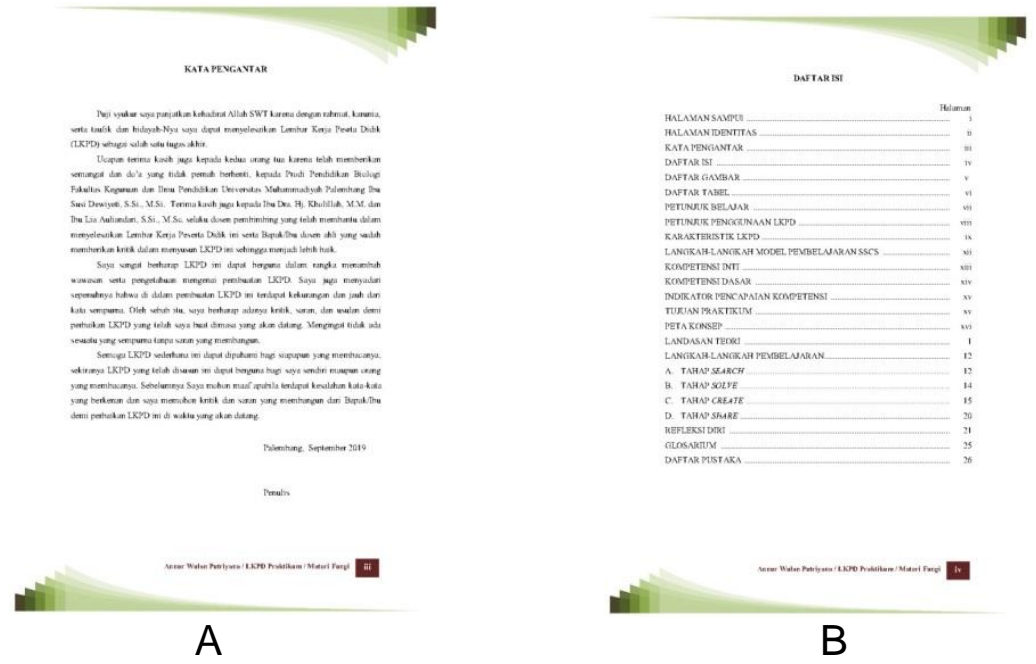

Gambar 3. (A) Penambahan Kata Pengantar sesuai masukan dari Validator Materi (B) Penambahan Daftar Isi sesuai masukan dari Validator Materi 

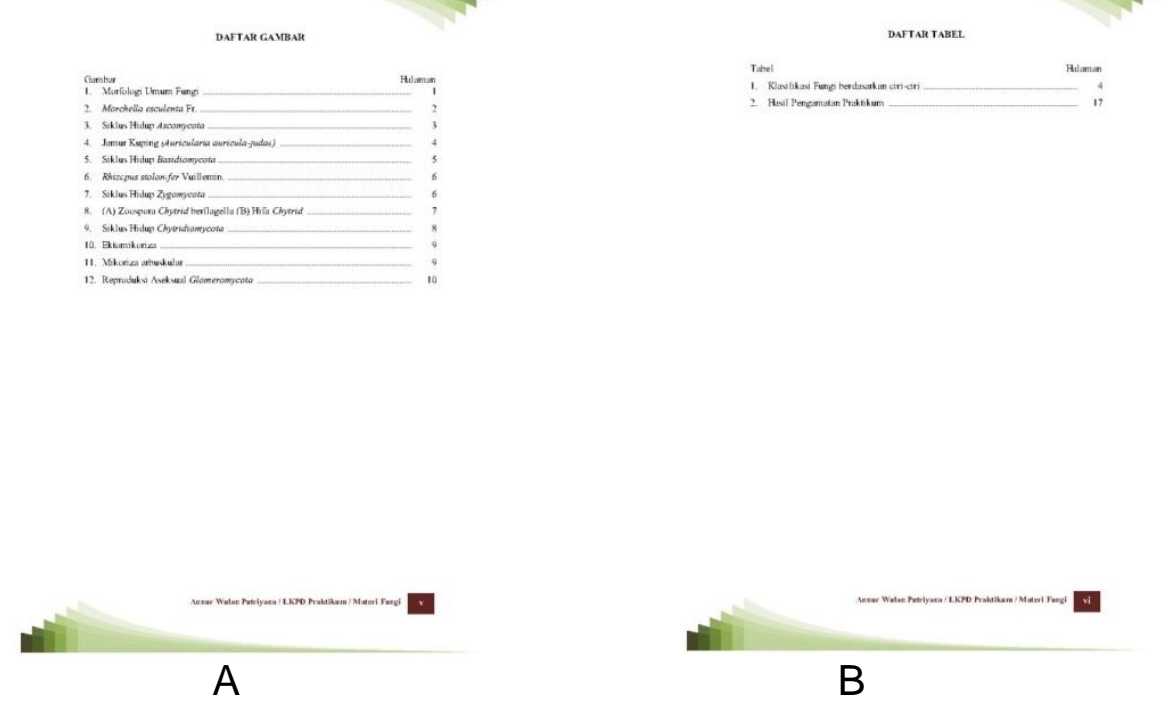

Gambar 4. (A) Penambahan Daftar Gambar sesuai masukan dari Validator Materi (B) Penambahan Daftar Tabel sesuai masukan dari Validator Materi
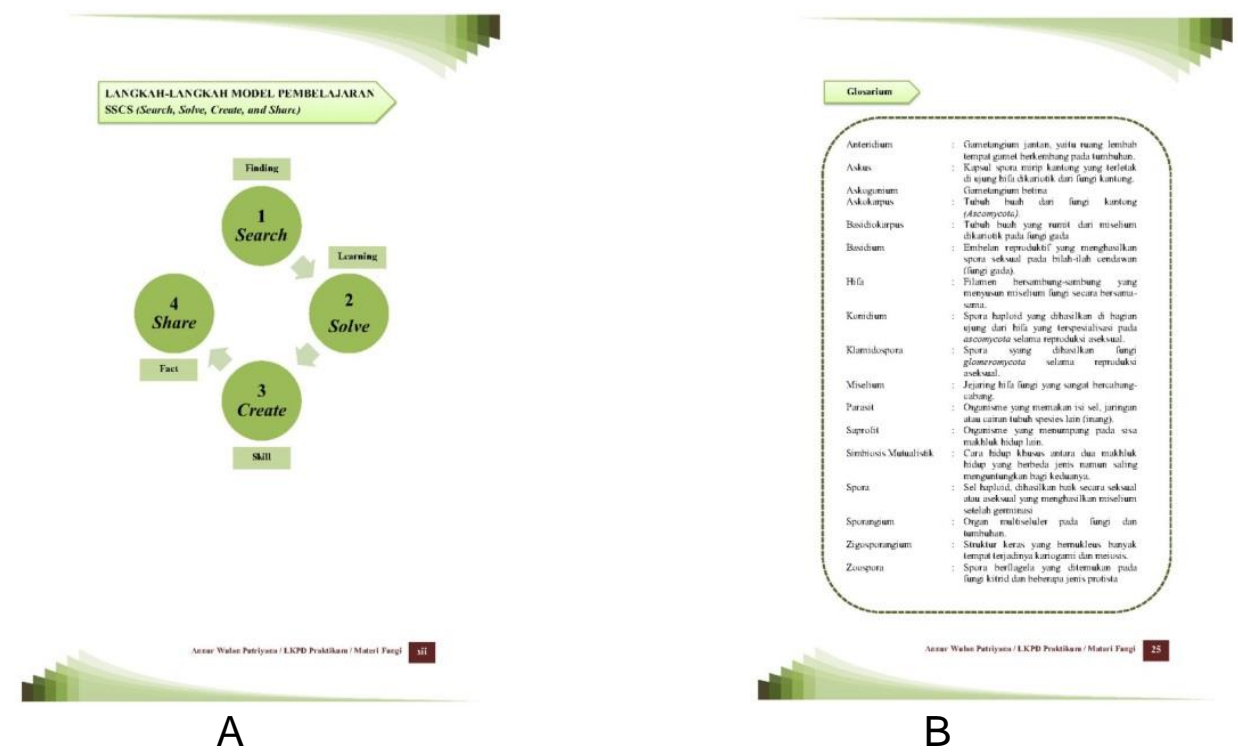

Gambar 5. (A) Penambahan Langkah-langkah Model Pembelajaran sesuai masukan dari Validator Materi (B) Penambahan Glosarium sesuai masukan dari Validator Materi

Hal ini pun sejalan dengan pendapat Prastowo (2015) yang menyatakan bahwa LKS terdiri dari enam komponen, yaitu judul, petunjuk belajar, kompetensi yang akan dicapai, informasi pendukung, tugas-tugas dan langkah-langkah kerja, serta penilaian. Ketika hendak membuat LKS, maka paling tidak enam komponen inti tersebut harus ada dan selebihnya bisa ditambahkan untuk membuat LKS lebih menarik lagi.

3. Hasil dan Pembahasan Oleh Pengguna (Guru)

Berdasarkan hasil validasi dari dua orang pengguna (guru), ada beberapa yang perlu diperbaiki dalam pembuatan LKPD yang diuji kelayakannya. Hasil penilaian dari ketiga validator materi kemudian dirata-ratakan dapat dilihat pada Tabel 4 diperoleh nilai 91 yang artinya bahan ajar LKPD termasuk kategori sangat layak berdasarkan penilaian pengguna (guru). 
Tabel 4 Hasil Validasi Oleh Pengguna (Guru)

\begin{tabular}{cccc}
\hline \multirow{2}{*}{ Indikator } & \multicolumn{2}{c}{ Penilaian Validator Bahan Ajar } & Rata-rata \\
\cline { 2 - 3 } & Validator 1 & Validator 2 & 91 \\
Jumlah & 96 & 86 & Sangat Layak \\
Kategori & Sangat Layak & Sanagat Layak & \\
\hline
\end{tabular}

Penilaian oleh pengguna (guru) ini dilakukan oleh dua orang pengguna untuk mengetahui kelayakan LKPD berbasis model pembelajaran SSCS (Search, Solve, Create and Share) pada praktikum materi Fungi didasarkan pada sepuluh indikator, yaitu meliputi kesesuaian materi dengan kompetensi dasar, keakuratan materi, kemutakhiran materi, mendorong keingintahuan, teknik penyajian, penyajian pembelajaran, lugas, dialogis dan interaktif, kesesuaian dengan kaidah bahasa indonesia dan penggunaan istilah, simbol atau ikon.

Berdasarkan hasil analisis penilaian pengguna (guru) yang tercantum dalam Tabel 4, pengguna pertama (guru) menyatakan bahwa LKPD tersebut sangat layak dan pengguna (guru) kedua menyatakan bahwa LKPD tersebut sangat layak. Hasil rata-rata dari kedua pengguna (guru) tersebut yaitu 91 yang artinya LKPD tersebut sangat layak.

Berdasarkan pehitungan dengan rumus Azwar (2014) bahan ajar LKPD telah dinyatakan layak karena telah memenuhi indikator Badan Standar Nasional Pendidikan (BSNP) dengan interval $84<\mathrm{X}$. Walaupun LKPD dinyatakan layak, namun ada beberapa revisi dari pengguna (guru) yaitu, penambahan peranan masing-masing filum Fungi dalam peta konsep agar sesuai dengan tujuan pembelajaran yang akan dicapai. Hasil revisi dari penilaian pengguna (guru) dapat dilihat pada Gambar 6.

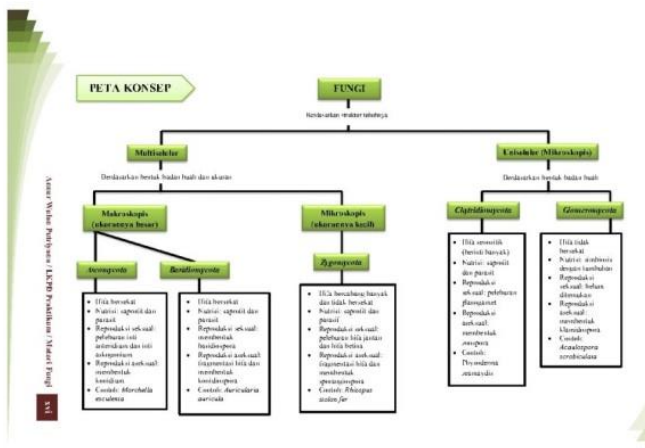

A

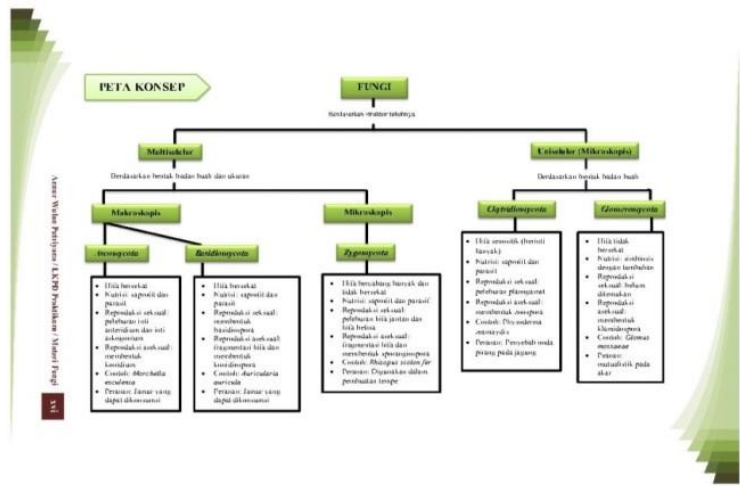

B

Gambar 6. (A) Peta Konsep sebelum direvisi oleh Pengguna (Guru) (B) Peta Konsep sesudah direvisi oleh pengguna (guru)

Keterangan: Peta konsep sebelum direvisi "tidak terdapat peranan fungi pada peta konsep". Sedangkan Peta konsep sesudah direvisi diberi peranan fungi pada setiap masing-masing filum agar sesuai dengan tujuan pembelajaran yang akan dicapai.

Hal ini pun sejalan dengan pendapat Rahmi (2017), pemahaman konsep merupakan pembelajaran yang bermakna, proses pembelajaran tidak sekedar menghafal konsep-konsep atau fakta-fakta belaka, tetapi merupakan kegiatan menghubungkan konsep-konsep untuk menghasilkan pemahaman yang utuh dan juga untuk mencapai tujuan pembelajaran. 


\section{KESIMPULAN}

Berdasarkan hasil penelitian yang telah dilakukan bahwa kelayakan LKPD diuji oleh Expert review yang terdiri dari 3 orang validator bahan ajar, 3 orang validator materi dan 2 orang pengguna (guru). Hasil rata-rata dari ketiga validator bahan ajar adalah 94,67 dengan interval 83,3 $<X \leq 99,9$ dikategorikan layak, hasil rata-rata dari ketiga validator materi adalah 77 dengan interval $66,6<X \leq 79,9$ dikategorikan layak dan hasil rata-rata dari kedua pengguna (guru) adalah 91 dengan interval $84<\mathrm{X}$ dikategorikan sangat layak.

\section{UCAPAN TERIMAKASIH}

Terimakasih kepada Allah SWT yang telah memberikan kesehatan selama penelitian ini berlangsung, terimakasih kepada kedua orang tua yang senantiasa memberi dukungan baik moril maupun materil, terimakasih juga kepada dosen pembimbing yang senantiasa tiada lelah dalam memberikan saran selama penelitian ini berlangsung, terimakasih juga untuk guru biologi SMA Patra Mandiri 1 Palembang dan terimakasih juga untuk beberapa pihak yang telah mendukung dan membantu penelitian ini.

\section{DAFTAR PUSTAKA}

Azwar, S. (2014). Penyusunan Skala Psikologi. Yogyakarta: Pustaka Belajar.

BalRam, R. (2017). Pengaruh Metode Praktikum Disertai Feedback Terhadap Hasil Belajar dan Respon Siswa Kelas X pada Materi Larutan. Jurnal Pendidikan Dan Pembelajaran Khatulistiwa, 6(6), 1-12.

Basri, U. K., Idris, I. D., Azis, A. A., Mu'nisa, A., Rahmawaty, Hala, Y., dan Jumadi, O. (2019). Pengembangan Lembar Kerja Peserta Didik ( LKPD ) Berbasis Potensi Lokal pada Materi Fungi untuk Siswa Kelas X SMK. Prosiding Seminar Nasional Lembaga Pengabdian Masyarakat Universitas Negeri Makassar, 670675.

Carolina, H. S., Sutanto, A., \& Suseno, N. (2017). Pengembangan Buku Ajar Perubahan Lingkungan Berbasis Model SSCS (Search, Solve, Create, Share) untuk Memberdayakan Kemampuan Berpikir Kritis. Didaktika Biologi, 1(2), 7987.

Dewi, R., Budiarti, R. S., \& Aina, M. (2017). Pengembangan lembar kegiatan peserta didik (lkpd) bermuatan pendidikan karakter dengan model pembelajaran guided inquiry pada materi bakteri bagi siswa kelas $x$ sekolah menengah atas. BIODIK, 3(1), 17-26. https://doi.org/10.22437/bio.v3i1.4878

Diniaty, A., dan Atun, S. (2015). Pengembangan Lembar Kerja Peserta Didik (LKPD) Industri Kecil Kimia Berorientasi Kewirausahaan Untuk SMK Artina. Inovasi Pendidikan IPA, 1(1), 46-56.

Elseria. (2016). Efektifitas Pengelolaan Laboratorium IPA. Manajer Pendiidkan, 10(1), 109-121.

Haqsari, R. (2014). Pengembangan dan Analisis E-LKPD (Elektronik-Lembar Kerja Pesert Didik) Berbasis Multimedia pada Materi Mengoperasikan Software Spreadsheet. Skripsi Universitas Negeri Yogyakarta.

Hidayati, N. (2012). Penerapan Metode Praktikum Dalam Pembelajaran Kimia untuk Meningkatkan Keterampilan Berfikir Tingkat Tinggi Siswa pada Materi Pokok 
Kesetimbangan Kimia Kelas XI SMK Diponegoro Banyuputih Batang. Skripsi Institut Agama Islam Negeri Walisongo Semarang.

Hidayati, U. (2013). Pemanfaatan Laboratorium IPA dan Bahasa pada Madrasah Aliyah Swasta. Edukasi, 11(1), 94-112.

Mujiarti, L. (2014). Pegembangan Buku Ajar Berbasis Gambar untuk Meningkatkan Hasil Belajar Siswa pada Mata Pelajaran IPS Materi Pokok Kenampakan Alam dan Buatan Kelas V Semester I MI Islamiyah Jatisari Nganjuk. Skripsi Universitas Islam Negeri Maulana Malik Ibrahim Malang.

Prastowo, A. (2015). Panduan Kreatif Membuat Bahan Ajar Inovatif. Yogyakarta: DIVA Press.

Puspa, S., Lubis, W., \& Rizkika, D. (2017). Efektivitas Penggunaan Laboratorium dalam pembelajaran Biologi Kelas $X$ di SMA Negeri 1 Unggul Baitussalam. Semdi Unaya, (November), 418-428.

Purnama, M. E. (2018). Pengembangan Lembar Kerja Peserta Didik (LKPD) Berbasis Multiple Intelligences Pada Materi Jamur Kelas X SMA. Skripsi Universitas Muhammadiyah Palembang.

Putri, D., dan Mitarlis. (2015). Pengembangan Lembar Kerja Siswa Berbasis Mind Mapping pada Materi Laju Reaksi untuk Melatihkan Keterampilan Berfikir Kreatif Siswa Kelas XI SMA. UNESA Journal of Chemical Education, 4(2), 340-348.

Rahmatika, F. (2014). Pengembangan Lembar Kerja Siswa Berbasis Search, Solve, Create, and Share pada Praktikum Mandiri Materi Mollusca dan Arthropoda. Skripsi Universitas Negeri Semarang.

Rahmatika, F., \& Alimah, S. (2012). Pengembangan Lembar Kerja Siswa Berbasis Search, Solve, Create, and Share pada Praktikum Mandiri Materi Mollusca dan Arthropoda. Unnes Journal of Biology Education, 1(1), 1-8.

Rahmi, L. (2017). Pengembangan Modul Pembelajaran Biologi Berorientasi Meaningful Learning disertai Peta Konsep pada Materi Sistem Peredaran Darah Kelas XI SMA. Nur El-Islam, 4(1), 65-77.

Sa'diyati, F. (2011). Pengembangan Bahan Ajar Materi Jamur Berbasis Kinerja Siswa. Skripsi Universitas Negeri Semarang.

Saputra, A., Sumarjono, \& Purwaningsih, E. (2014). Pengaruh model Pembelajaran Search, Solve, Create and Share dengan Metode Resitasi Terhadap Kemampuan Penguasaan Konsep Fisika Siswa Kelas XI SMAN 9 Malang. Skripsi Universitas Negeri Malang.

Sobiroh, A. (2006). Pemanfaatan Laboratorium untuk Meningkatkan Hasil Belajar Biologi Siswa Kelas 2 SMA Se-Kabupaten Banjarnegara Semester 1 Tahun 2004/2005. Skripsi Universitas Negeri Malang. 